\title{
Perturbed Microbiota/Immune Homeostasis in Multiple Sclerosis
}

Delphine Sterlin, PharmD, PhD, Martin Larsen, PhD, Jehane Fadlallah, MD, PhD, Christophe Parizot, MS, Marina Vignes, PharmD, Gaëlle Autaa, MS, Karim Dorgham, PhD, Catherine Juste, PhD, Patricia Lepage, PhD, Jennifer Aboab, MD, Savine Vicart, MD, Elisabeth Maillart, MD, Olivier Gout, MD, Catherine Lubetzki, MD, PhD, Romain Deschamps, MD, Caroline Papeix, MD, and Guy Gorochov, MD, PhD

Neurol Neuroimmunol Neuroinflamm 2021;8:e997. doi:10.1212/NXI.0000000000000997

\begin{abstract}
Objective

Based on animal models and human studies, there is now strong suspicion that host/microbiota mutualism in the context of gut microbial dysbiosis could influence immunity and multiple sclerosis (MS) evolution. Our goal was to seek evidence of deregulated microbiota-induced systemic immune responses in patients with MS.
\end{abstract}

\section{Methods}

We investigated gut and systemic commensal-specific antibody responses in healthy controls $(\mathrm{n}=32)$, patients with relapsing-remitting MS $(\mathrm{n}=30)$, and individuals with clinically isolated syndromes (CISs) $(n=15)$. Gut microbiota composition and diversity were compared between controls and patients by analysis of $16 \mathrm{~S}$ ribosomal ribonucleic acid (rRNA) sequencing. Autologous microbiota and cultivable bacterial strains were used in bacterial flow cytometry assays to quantify autologous serum IgG and secretory IgA responses to microbiota. IgG-bound bacteria were sorted by flow cytometry and identified using $16 \mathrm{~S}$ rRNA sequencing.

\section{Results}

We show that commensal-specific gut IgA responses are drastically reduced in patients with severe MS, disease severity being correlated with the IgA-coated fecal microbiota fraction $(r=$ $-0.647, p<0.0001)$. At the same time, IgA-unbound bacteria elicit qualitatively broad and quantitatively increased serum IgG responses in patients with MS and CIS compared with controls ( $4.1 \%$ and $2.5 \%$ vs $1.9 \%$, respectively, $p<0.001$ ).

\section{Conclusions}

Gut and systemic microbiota/immune homeostasis are perturbed in MS. Our results argue that defective IgA responses in MS are linked to a breakdown of systemic tolerance to gut microbiota leading to an enhanced triggering of systemic IgG immunity against gut commensals occurring early in MS.

\author{
Correspondence \\ Prof. Gorochov \\ guy.gorochov@ \\ sorbonne-universite.fr
}




\section{Glossary}

CFU = colony-forming unit; CIS = clinically isolated syndrome; EAE = experimental autoimmune encephalomyelitis; EDSS = Extended Disability Status Scale; EI = enrichment index; GBS = Guillain-Barré syndrome; IMD = immunomodulatory; MBP = myelin basic protein; $\mathbf{M S}=$ multiple sclerosis; OTU = operational taxonomic unit; $\mathbf{P B S}=$ phosphate buffer saline; $\mathbf{P C R}=$ polymerase chain reaction; $\mathbf{R N A}$ = ribosomal ribonucleic acid; $\mathbf{R R}=$ relapsing-remitting; $\mathbf{T N F}=$ tumor necrosis factor.

Over the years, many microbes have been proposed as potential multiple sclerosis (MS) triggers, but firm evidence for causality has never been provided. A seminal murine study, however, exploiting germ-free mice engineered to develop spontaneous experimental autoimmune encephalomyelitis (EAE) suggested that commensal gut bacteria contribute to the disease process. ${ }^{1}$ Microbiota transfer from patients with MS into mice was then shown to induce and/or exacerbate symptoms, using the same spontaneous model, ${ }^{1}$ or a more classic model in which EAE is actively induced following colonization. ${ }^{2}$

In patients with MS, increased fecal abundances of Akkermansia, Blautia, Ruminococcus, and Bifidobacterium genera have been described, whereas Faecalibacterium, Parabacteroides, Prevotella, and Lactobacillus would have a relatively low abundance compared with healthy controls. ${ }^{345}$ Most studies supported, based on in vitro assays and murine models, that MS microbiota composition affects host immune responses, driving an impaired T-cell differentiation to $\mathrm{CD} 25^{+}$ FoxP $3^{+}$regulatory $\mathrm{T}$ cells and inclined differentiation toward proinflammatory Th1 and Th17 cells, ${ }^{2,6}$ or proinflammatory changes in monocytes. ${ }^{5}$ The effect of immunomodulatory (IMD) therapy was examined in multiple studies, indicating that treatment might normalize the abundance of some microbial taxa such as Prevotella and Sutterella, ${ }^{5}$ yet affect other microbial taxa such as Methanobrevibacter, ${ }^{5,7,8}$ Akkermansia muciniphila, ${ }^{5,7}$ Roseburia, and Clostridium cluster IV. ${ }^{8,9}$ We hypothesized that such gut microbiota alterations may affect host humoral responses.

Original events leading to a breakdown of tolerance and generation of autoimmune response are still poorly understood in MS. The molecular mimicry theory argues in favor of homologies between microbial components and human proteins likely taking part in the development of systemic and/or CNS autoimmune diseases. Both commensal and pathogenic strains could lead to autoimmune responses through molecular mimicry. In neuromyelitis optica, patients develop autoantibodies against aquaporin 4, the predominant astrocyte water channel, which cross-react with an adenosine triphosphate-binding cassette transporter of Clostridium perfringens. ${ }^{10,11}$ Likewise, GuillainBarré syndrome (GBS) has been associated with Campylobacter jejuni, a leading agent of bacterial gastroenteritis. ${ }^{12}$ GBS pathogenesis would be related in some instances to the induction of antibodies cross-reacting with $C$. jejuni surface polysaccharides and similar human myelin-associated ganglioside structures. ${ }^{13}$ However, systemic immune responses to autologous microbiota were never extensively explored in patients with MS.
Here, we investigated gut and systemic antibody antimicrobiota responses in patients with MS. We report that intestinal IgA interacts with a reduced proportion of commensal bacteria in patients with severe MS. Aberrant antimicrobiota $\operatorname{IgG}$ responses, associated with symptoms of bacterial translocation, are also observed.

\section{Methods}

\section{Patients}

In the present study, 18 patients with clinically isolated syndromes (CISs) (feces and serum were together available for only 12 of them), 32 patients with relapsing-remitting (RR)MS, and 30 age- and sex-matched healthy individuals have been enrolled. Patients with CIS and RR-MS were recruited either at the Fondation Ophtalmologique Adolphe de Rothschild (Paris, France) or at the Department of Neurology of Pitié-Salpêtrière Hospital (Paris, France). Patients with RRMS fulfilled McDonald diagnostic criteria for MS. ${ }^{14}$ Patient disability was assessed using the Expanded Disability Status Scale (EDSS), ${ }^{15}$ which ranges from 0 (no disability) to 10 (death), with 0.5 unit increments. EDSS of included patients ranged between 0 and 6.5. CIS was defined as a first CNS inflammatory event that lasts at least 24 hours. ${ }^{16,17} \mathrm{IMD}$ treatments including glatiramer acetate and IFN- $\beta$ were reported in the table. Blood and stool collection occurred before steroid therapy in patients with CIS and RR-MS. The inclusion criteria specified no use of corticosteroids, antibiotics, or laxative drugs in the last 3 months prior the study. Detailed patient information is summarized in the table. Fresh stool and blood samples were collected simultaneously at a single time point.

\section{Stool Processing, Microbiota Purification, and Processing}

Stool samples were collected in a container including a reagent for the generation of an $\mathrm{O}_{2}$-depleted and $\mathrm{CO}_{2}$-enriched atmosphere (Anaerocult band, Mikrobiologie), aliquoted in an anaerobic atmosphere, and stored at $-80^{\circ} \mathrm{C}$. Fecal bacteria were purified by gradient purification as previously described. ${ }^{18,19}$ Bacterial extracts were suspended in 1xPBS (phosphate buffer saline) $-10 \%$ glycerol, immediately frozen in liquid nitrogen, and then stored at $-80^{\circ} \mathrm{C}$. Genomic DNA was extracted from whole stool samples as previously described..$^{20}$ Briefly, $200 \mathrm{mg}$ of fecal sample was lysed chemically (guanidine thiocyanate and N-lauroyl sarcosine) and mechanically (glass beads) followed by elimination of cell debris by centrifugation and precipitation of genomic DNA. Finally, genomic DNA was RNase 
Table Demographic and Clinical Features of the Cohort

\begin{tabular}{|c|c|c|c|}
\hline & $\begin{array}{l}\text { Healthy } \\
\text { donors }\end{array}$ & RR-MS & CIS-MS \\
\hline Sex (H/F) & $12 / 20$ & $11 / 19$ & $5 / 13$ \\
\hline BMI & $\begin{array}{l}21.8 \\
(18.7-31.9)\end{array}$ & $\begin{array}{l}22.6 \\
(16.4-32.7)\end{array}$ & $\begin{array}{l}22.9 \\
(18.4-39.1)\end{array}$ \\
\hline Age & $\begin{array}{l}32.9 \\
(23.6-61.3)\end{array}$ & $\begin{array}{l}38.4 \\
(18.9-60.6)\end{array}$ & $\begin{array}{l}31.8 \\
(18.1-54.8)\end{array}$ \\
\hline Age at onset & NA & $\begin{array}{l}29.8 \\
(12.3-53.2)\end{array}$ & $\begin{array}{l}31.5 \\
(18-54.7)\end{array}$ \\
\hline $\begin{array}{l}\text { Duration of the } \\
\text { disease }\end{array}$ & NA & $7(0.5-26)$ & NA \\
\hline \multicolumn{4}{|l|}{ EDSS score } \\
\hline$<3$ & NA & 18 & 14 \\
\hline $3-5$ & NA & 10 & 4 \\
\hline$>5$ & NA & 2 & 0 \\
\hline \multicolumn{4}{|l|}{ Treatment } \\
\hline IFN- $\beta$ & 0 & 8 & NA \\
\hline $\begin{array}{l}\text { Glatiramer } \\
\text { acetate }\end{array}$ & 0 & 6 & NA \\
\hline Mitoxantrone & 0 & 1 & NA \\
\hline Solumedrol & 0 & 1 & NA \\
\hline Natalizumab & 0 & 1 & NA \\
\hline w/o (or ND) & & $10(3)$ & NA \\
\hline
\end{tabular}

Abbreviations: $\mathrm{BMI}=$ body mass index; IFN = interferon; NA = not applicable; $\mathrm{w} / \mathrm{o}=$ without .

Numbers for ages and duration of the disease refer to years.

treated. DNA concentration was estimated by Nanodrop (Thermo Scientific).

\section{Bacterial Strains and Culture Conditions}

Prevotella oris and Fusobacterium nucleatum were isolated from human samples and identified by matrix-assisted laser desorption ionization-time of flight mass spectrometry (Microbiology Department, Pitié-Salpêtrière Hospital, Paris). Both bacterial strains were cultured on sheep red blood agar plates at $37^{\circ} \mathrm{C}$ under anaerobic conditions for 48 hours. Ruminococcus obeum (VPI B321), Bacteroides caccae (VPI 3452A), Bifidobacterium longum (E194v variant A), and Akkermansia muciniphila (DSM-22959) were characterized at the Institut National de Recherche Agronomique (Jouy-en-Josas, France). A muciniphila was cultured in L-YHBHI.4 medium (Liquid-Yeast extract Hemin Brain Heart Infusion) with mucin, whereas $R$ obeum was cultured in PYG medium (peptone-yeast extract-dextrose) at $37^{\circ} \mathrm{C}$ under anaerobic conditions. Bacterial cultures were suspended in 1xPBS-10\% glycerol $\left(10^{9}\right.$ colony-forming units $\left.[\mathrm{CFUs}] / \mathrm{mL}\right)$ and frozen at $-80^{\circ} \mathrm{C}$. Quantification of CFUs was performed by adding counting beads (Beckman Coulter) to bacterial suspensions and then analyzed by flow cytometry (FACSCanto II, BD).

\section{Bacterial Flow Cytometry}

Systemic IgG and secretory IgA binding to microbiota was assessed by bacterial flow cytometry as previously described. ${ }^{21}$ Briefly, thawed microbiota or bacterial strains ( $10^{7}$ bacteria/ conditions) were fixed in a solution of $4 \%$ paraformaldehyde and stained with Cell Proliferation Dye eFluor 450 (eBioscience). After washing with $1 \times P B S\left(10\right.$ minutes, $4,000 g, 4^{\circ} \mathrm{C}$ ), cells were suspended in 1xPBS, 2\% bovine serum albumin (Sigma), and $0.02 \%$ sodium azide (Sigma) and incubated in a $96-\mathrm{V}$ bottom well plate with a $10 \mu \mathrm{g} / \mathrm{mL}$ IgG solution (from either human serum or pooled human IgG Hizentra-CSL Behring France or human anti-tumor necrosis factor (TNF) Remicade ${ }^{-}$MSD France) per condition. All buffers were passed through sterile $0.22-\mu \mathrm{m}$ filters before use. After washing, secondary conjugated antibodies (goat anti-human IgA-FITC and goat anti-human IgG-A647) or isotype controls (both from Jackson ImmunoResearch Laboratories, West Grove) were added for 20 minutes at $4^{\circ} \mathrm{C}$. Then, bacteria were suspended in sterile PBS. Thirty thousand bacterial events were acquired on a FACSCanto II flow cytometer (Becton Dickinson). Analysis was performed with FlowJo software (Treestar). Frequencies of Ig-bound microbiota were expressed as percentages, median, minimum, and maximum values throughout the article. Medians of fluorescence were used to measure IgG-binding levels for pure bacterial strains.

\section{S Ribosomal RNA Phylogenetic Analysis of Total Gut Microbiota and IgG-Coated Fractions} Purified microbiota $\left(10^{8} /\right.$ condition) was washed in $1 x$ PBS and stained with secondary conjugated antibodies (goat antihuman IgA-FITC and goat anti-human IgG-A647) or isotype controls (both from Jackson ImmunoResearch Laboratories, West Grove). After washing, sorting was performed using a microbiota-dedicated single laser S3 cell sorter (Bio-Rad Laboratories, CA). $10^{5}$ bacteria per fraction was collected in $1 \mathrm{xPBS}$, centrifuged, and immediately stored as dry pellets at $-80^{\circ} \mathrm{C}$. Purity for both fractions was systematically verified after sorting. DNA was extracted, and the V3-V4 region of the $16 \mathrm{~S}$ ribosomal ribonucleic acid (rRNA) gene was amplified by seminested polymerase chain reaction (PCR). Primers V3fwd (+357): $5^{\prime}$ TACGGRAGGCAGCAG $3^{\prime}$ and V4rev (+857): 5' ATCTTACCAGGGTATCTAATCCT 3' were used during the first round of PCR (10 cycles). Primers V3fwd and X926_Rev (+926) 5' CCGTCAATTCMTTTRAGT 3 ' were used in the second PCR round (40 cycles). PCR amplicon libraries were sequenced using a MiSeq Illumina platform (Genotoul, Toulouse, France). The resulting sequences from whole microbiota were analyzed using the open source software package Quantitative Insights Into Microbial Ecology ${ }^{22}$ as previously described. ${ }^{23}$ Demultiplexed reads from IgG-coated bacteria were processed using MGRAST analysis pipeline. Sequencing artifacts, host DNA contamination, and sequences less than $200 \mathrm{bp}$ in length were removed. Insufficient quality reads were discarded $(<5 \%$ of total reads). Sequences were then clustered into operational taxonomic units (OTUs) with a 97\% homology using Greengenes database. OTUs containing only a single sequence were discarded. OTUs detected at $>0.1 \%$ relative 
abundance in at least 2 samples were finally conserved. This process reduced the total OTU count from 297 down to 102. OTU table was rarefied to the minimum sample's depth (18,727 reads). Shannon index was calculated according to the following equation: Shannon index $=-\Sigma p_{i} \ln \left(p_{i}\right)$ where $p_{i}$ is the relative abundance of the $i$ th OTU in the data set. In calculating the enrichment index (EI), we scored a pseudorelative abundance equal to 0.0001 , which was the lower limit of detection, if a taxon was not detected in a given fraction. $\mathrm{IgA}^{-} \mathrm{IgG}^{+}$EI refers to:

$$
\log 10\left(\frac{\operatorname{Ig} A-\operatorname{Ig} G+\text { taxon abundance }}{\operatorname{Ig} A-\operatorname{Ig} G-\text { taxon abundance }}\right)
$$

$$
\text { and } \operatorname{Ig} \mathrm{A}^{+} \operatorname{IgG}{ }^{+} \text {EI to } \log 10\left(\frac{\operatorname{IgA}+\operatorname{Ig} G+\text { taxon abundance }}{\operatorname{IgA}-\operatorname{Ig} G-\text { taxon abundance }}\right) \text {. }
$$

\section{Statistical Analysis}

Statistical analysis was performed using Graphpad Prism v6. The Wilcoxon paired rank test was used when comparing paired groups, whereas the Mann-Whitney test was used when comparing 2 independent groups. For multiple comparisons, the Kruskall-Wallis test with post hoc Dunn test was conducted. Significant $p$ values are indicated on plots $\left({ }^{*} p<\right.$ $\left.0.05 ;^{* *} p<0.01 ;^{* * *}<0.001\right)$.

\section{Standard Protocol Approvals, Registrations, and Patient Consents}

The study had been approved by the local ethics committee of Pitié-Salpêtrière Hospital (CPP Ile de France VI). A prior written consent was obtained from all the patients and controls before inclusion in the study.

\section{Data Availability}

All relevant data are available within the article. Anonymized data are available and will be shared on request from any qualified investigator.

\section{Results}

\section{Collapsed IgA Interactions With Fecal Microbiota in Patients With Severe MS}

We postulated that not only microbiota composition ${ }^{345}$ but also the immune/microbiota interface could be perturbed in MS. We first compared IgA-bound fecal microbiota levels in healthy donors and patients with MS. In accordance with previous studies, ${ }^{19}$ we observed in the control group used for the present study that IgA binds a median percentage of $7.6 \%$ $(0.8 \%-18.8 \%, \mathrm{n}=30)$ of the whole fecal microbiota (figure 1, A and B). The proportion of IgA-bound fecal microbiota is not significantly decreased in patients with MS (median [min$\max ] \% ; 5.1[0.2-27.2] \% ; \mathrm{n}=32$, figure $1, \mathrm{~A}$ and B) compared with controls $(p=0.33)$. We then evaluated whether the IgA/ microbiota interface could be more perturbed in severely affected patients. Disease severity at the time of serum and microbiota sampling was evaluated using the Extended Disability Status Scale (EDSS). ${ }^{24}$ We observed that disabled patients with RR-MS (EDSS score $>4$ ) had significantly reduced proportions of IgA-bound fecal bacteria compared with patients with RR-MS without disability (EDSS score <2) (1.02 [0.24-6.02]\% vs $12.3[1.49-27.23] \%$ respectively, $p<0.001$, figure $1, C)$. Strikingly, disease severity is inversely correlated with the IgA-coated fecal microbiota fraction at the individual level $(r=$ $-0.647, p<0.0001$; figure $1, D)$. Because the majority of severe patients were on immunosuppressive treatment, we sought to explore whether IMD therapies might alter IgA responses. We found no difference in IgA-coated proportions of fecal microbiota between untreated and treated patients (figure e-1, A, links.lww. com/NXI/A468). Moreover, interferon- and glatiramer-treated patients exhibited similar IgA-bound fecal microbiota levels compared with untreated patients with MS (figure e-1, A, links. lww.com/NXI/A468). These results argue for a defective survey of the gut microbiota by IgA in disabled patients with MS.

\section{MS-Associated Gut Microbiota Dysbiosis}

We reasoned that defective IgA responses in disabled patients with MS might be related to differences in gut microbiota composition. We therefore performed 16S rRNA sequencing and identified bacterial taxa at the genus level. We first examined the microbial diversity by calculating the Shannon index. We found that alpha-diversity, i.e.,: the number of different species within a sample, was not different between healthy donors and patients with MS (median [min-max]; 0.51 [0.30-0.59] vs 0.53 [0.39-0.61]; $p=0.19$, figure e-2, A, links.lww.com/NXI/A469). However, neither disease severity nor treatments appeared to affect bacterial diversity (figure e-2, A, links.lww.com/NXI/ A469). We next investigated the frequency of prevalent genera ( $>1 \%$ in any sample group). Consistent with previous findings, ${ }^{8}$ the relative abundance of Clostridium cluster IV was increased in patients with MS compared with healthy donors $\left(5.1 \times 10^{-3}[5.4\right.$ $\left.\times 10^{-4}-0.03\right]$ vs $0.02\left[1.5 \times 10^{-3} \times 0.11\right] ; p=0.02$, figure e- $2, \mathrm{~B}$, links.lww.com/NXI/A469). This difference was mainly driven by a drastic increase of Clostridium cluster IV in disabled patients $\left(0.022\left[3.1 \times 10^{-3}-0.11\right]\right.$ in patients with EDSS score $>2, p=$ 0.0011; figure e-2, C, links.lww.com/NXI/A469). As previously described, ${ }^{5}$ we found that Prevotella tended to be underrepresented in patients with MS $\left(1.5 \times 10^{-3}[0-0.36]\right.$ vs 0.04 [0-0.6]; $p=0.09$, figure e-2, B, links.lww.com/NXI/A469). We also observed a decrease in the genus Coprococcus $(0.01[2 \times$ $\left.10^{-4}-0.07\right]$ vs 0.017 [0-0.08]; $p=0.12$, figure e-2, A, links.lww. com/NXI/A469). In both cases, these alterations tended to be more profound in severe cases (figure e-2, C, links.lww.com/ NXI/A469). Previous reports described effects of IMD therapies on gut microbiota composition. ${ }^{5,8,9}$ We therefore compared most prevalent genera in untreated, interferon-, and glatiramertreated patients and healthy donors. Although unclassified Clostridiales tended to be increased in interferon-treated patients $\left(0.08\left[1.7 \times 10^{-4}-0.14\right]\right.$ vs $0.009\left[9.3 \times 10^{-5}-0.06\right]$ in healthy donors; $p=0.06$, figure e-3, links.lww.com/NXI/A470), we did not observe statistically significant differences between groups, which is likely explained by the limited number of patients in each subgroup. Taken together, these results indicate subtle differences in the gut microbial communities in patients with MS that might modulate gut IgA responses. 
A
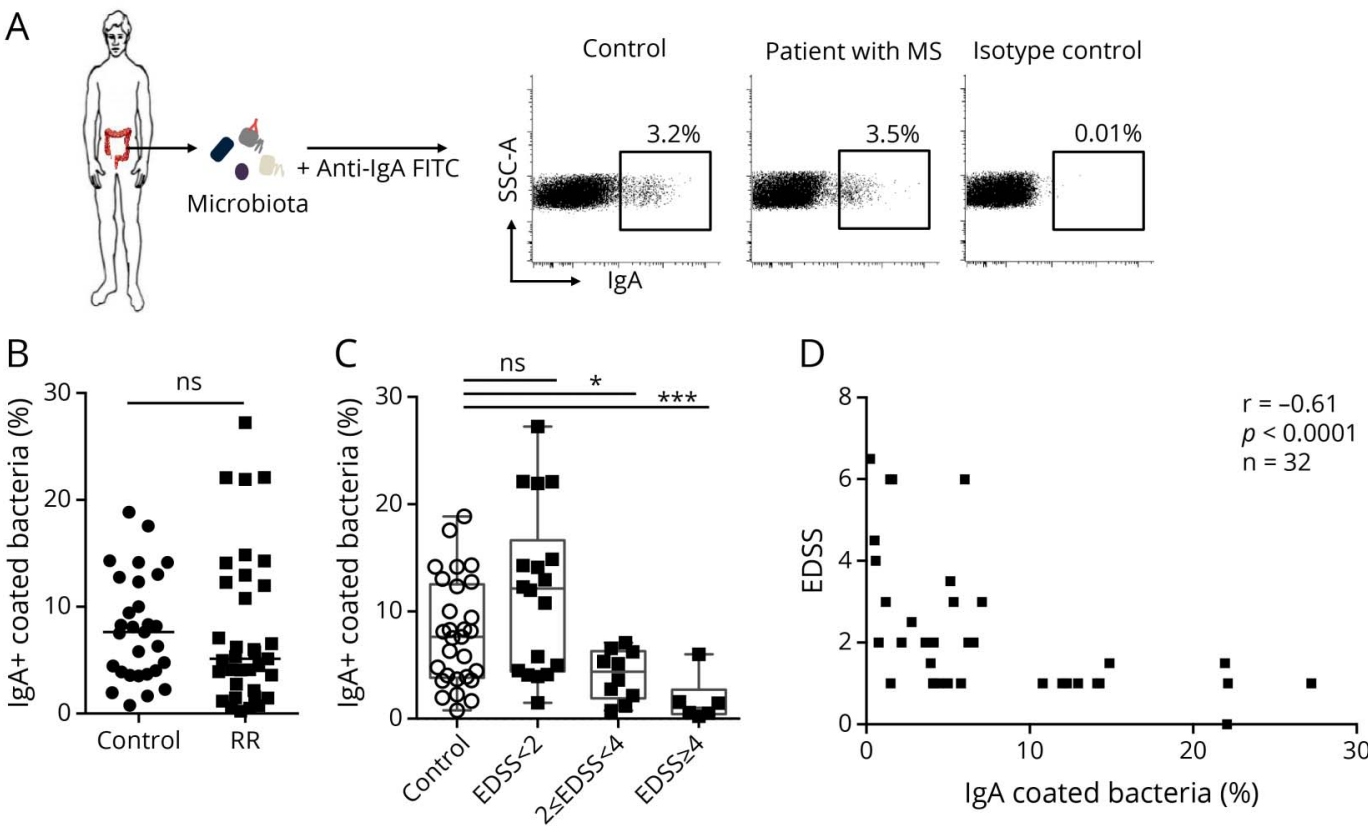

(A) Representative Flow Cytometry Dot Plot Showing Endogenous Secretory IgA Coating on Indicated Fractions of Fecal Microbiota From a Healthy Donor or a Patient With RR-MS (B) Flow cytometry analysis of the fraction of fecal microbiota bound by secretory IgA in healthy donors ( $\mathrm{n}=32$ ) and patients with RR-MS ( $\mathrm{n}$ = 32). Median values are indicated, and groups were compared with a nonparametric Mann-Whitney test (ns, not significant). (C) Flow cytometry analysis of the fraction of fecal microbiota bound by secretory IgA in healthy donors $(n=32)$ and patients with RR-MS classified according to disease severity, measured by the EDSS. Median values are indicated. Error bars represent minimum and maximum values. $p$ Values were calculated using the nonparametric MannWhitney test $\left({ }^{*} p<0.05 ; * \star \star p<0.001\right)$. (D) Disease severity evaluated by the EDSS correlated with the percentage of secretory IgA-bound microbiota in patients with MS-RR. Spearman coefficient $(r)$ and $p$ values are indicated. MS = multiple sclerosis; RR = relapsing-remitting.

\section{Exacerbated Antimicrobiota IgG Response in Patients With MS}

We then postulated that the perturbed gut IgA/microbiota interface observed above could translate into abnormal systemic anticommensal immune responses in patients. Indeed, the humoral response to microbiota is not gut confined, as high anticommensal IgGs are detected in healthy donor's serum. ${ }^{23,25,26}$ We used a previously described flow cytometric assay ${ }^{21}$ to concomitantly detect secretory IgA and serum IgG binding to autologous fecal microbiota (figure 2, A). Of note, IgG is about 5 times more abundant in serum than $\operatorname{IgA}$; consequently, this protocol allows us to detect serum IgG, but not serum IgA binding to fecal microbiota, as shown in figure e-4, A, links.lww. com/NXI/A471. Moreover, IgG is not transferred in the gut lumen leading to a negligible IgG-bound bacteria fraction in human feces (figure e-4, B, links.lww.com/NXI/A471). ${ }^{23}$ Altogether, this assay measured specifically secretory IgA prebound locally in the gut and serum IgG binding without interference of serum IgA, nor intestinal IgG. We found both quantitative and qualitative antimicrobiota $\operatorname{IgG}$ alterations in patients with MS regardless of disease severity. As shown, MS serum IgG interacts with a broader proportion of fecal microbiota compared with controls $(6.7[0.5-17.1] \%, \mathrm{n}=32$ vs $1.1[0.2-3.2] \%, \mathrm{n}=30, p<$ 0.0001 , figure $2, \mathrm{~B})$.

To investigate whether IgG binding to fecal bacteria is rather Fc or Fab dependent, we tested the reactivity of an irrelevant human IgG (chimeric anti-human TNF) against MS fecal microbiota. As shown, irrelevant human IgG binding to MS microbiota is significantly reduced compared with autologous serum IgG (0.6 [0-2.2]\% vs $6.7[0.5-17.1] \%, p<0.0001$, figure $2, \mathrm{C}$ ), indicating that serum IgG targets fecal microbiota in a mostly Fab-mediated manner.

We then asked whether disease duration or treatments could skew antimicrobiota IgG response. As shown, recently diagnosed and untreated patients with CIS also exhibit an enhanced antimicrobiota IgG response compared with controls (5.5 [3.4-8.4]\%, $\mathrm{n}=12$ vs $1.1[0.2-3.2] \%, \mathrm{n}=30, p<0.0001$, figure $2, \mathrm{~B})$. Finally, $\mathrm{IgG}+$ proportions of autologous microbiota did not significantly differ between treated and untreated patients with RR-MS (7.2 $[0.5-17.1] \% \mathrm{n}=16$ vs untreated patients $5.4[0.5-8.5] \% \mathrm{n}=10, p$ $=0.41$, figure e-1, B, links.lww.com/NXI/A468). Taken together, these data reveal an enhanced triggering of systemic IgG immunity against gut microbiota occurring early in MS.

\section{Loss of Antimicrobiota IgA/IgG Convergence in MS}

We previously observed that serum antimicrobiota IgG converges with secretory IgA to target the same bacterial cells in healthy individuals. ${ }^{23}$ As expected, serum IgG exclusively colabels secretory IgA-bound fecal bacteria in healthy donors, ${ }^{23}$ but preferentially targets IgA-unbound bacteria in patients with MS (1.9\% [0.2-6.9] in healthy donors $(n=30)$ vs $4.1 \%$ 

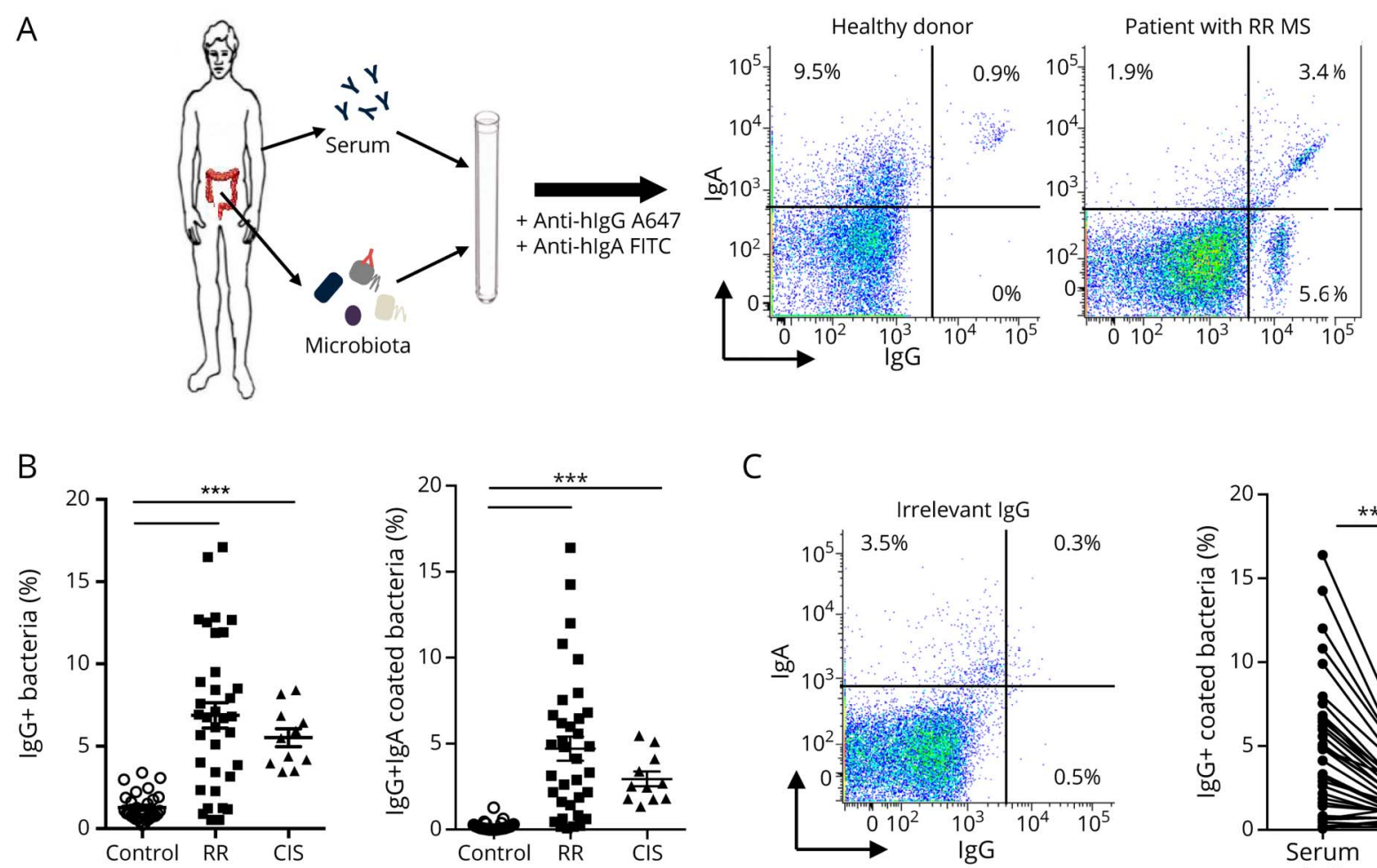

C
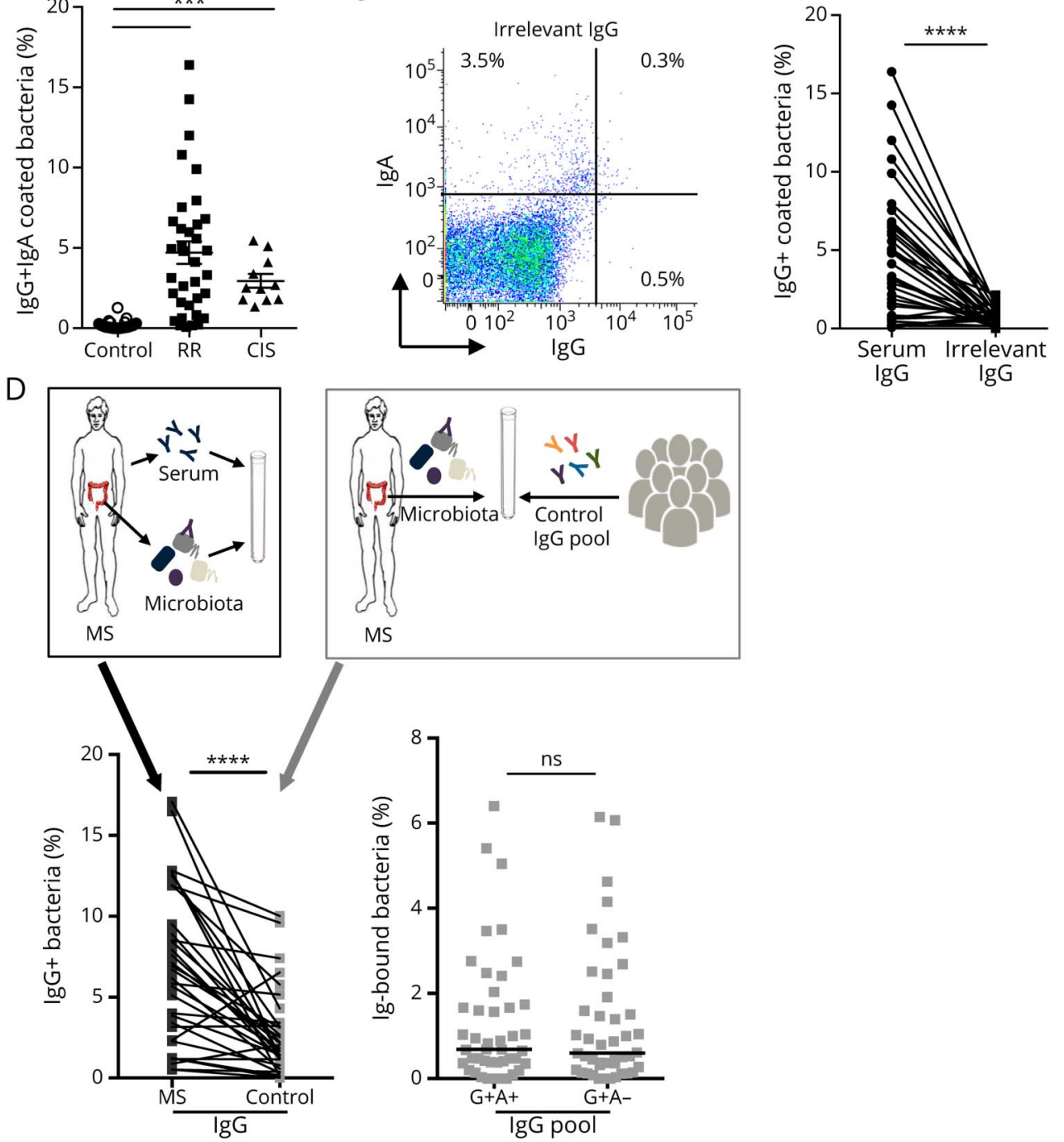

(A) Procedure (top) and representative flow cytometry detection (bottom) of endogenous secretory IgA and autologous systemic $\mathrm{lgG}(10 \mu \mathrm{gg} / \mathrm{mL}$ ) coating on healthy or RR-MS fecal microbiota is presented (middle panels). (B) Proportions of $\operatorname{lgG}{ }^{+} \lg A^{ \pm}$(left) and lgG ${ }^{+} \lg A^{-}$(right) coated bacteria are compared in healthy donors $(n=30)$, patients with RR-MS $(n=32)$, or patients with CIS $(n=12)$. Median values are indicated. $p$ Values were calculated using the nonparametric Mann-Whitney test $(* * * p<0.001)$. (C) Representative flow cytometry dot plot (left) and analysis (right) of irrelevant IgG (anti-TNFa $10 \mu \mathrm{g} / \mathrm{mL}$ ) binding to RR-MS and CIS fecal microbiota $(n=44)$. (D) Procedure (top), representative flow cytometry dot plot (middle panel) and analysis (bottom) of autologous lgG or pooled healthy IgG binding to RR-MS fecal microbiota $(n=32)$. Proportions of $\lg G^{+} \lg A^{ \pm}$coated bacteria (bottom left), $\operatorname{lgG}{ }^{+} \lg A^{+}$and $\lg G^{+} \lg A^{-}$coated bacteria (bottom right) are shown. $p$ Value was calculated by using the Wilcoxon paired test ( $\star \star \star \star p<0.0001 ; \mathrm{ns}=$ nonsignificant). $\mathrm{CIS}=$ clinically isolated syndrome; $\mathrm{MS}=$ multiple sclerosis; RR = relapsing-remitting. 

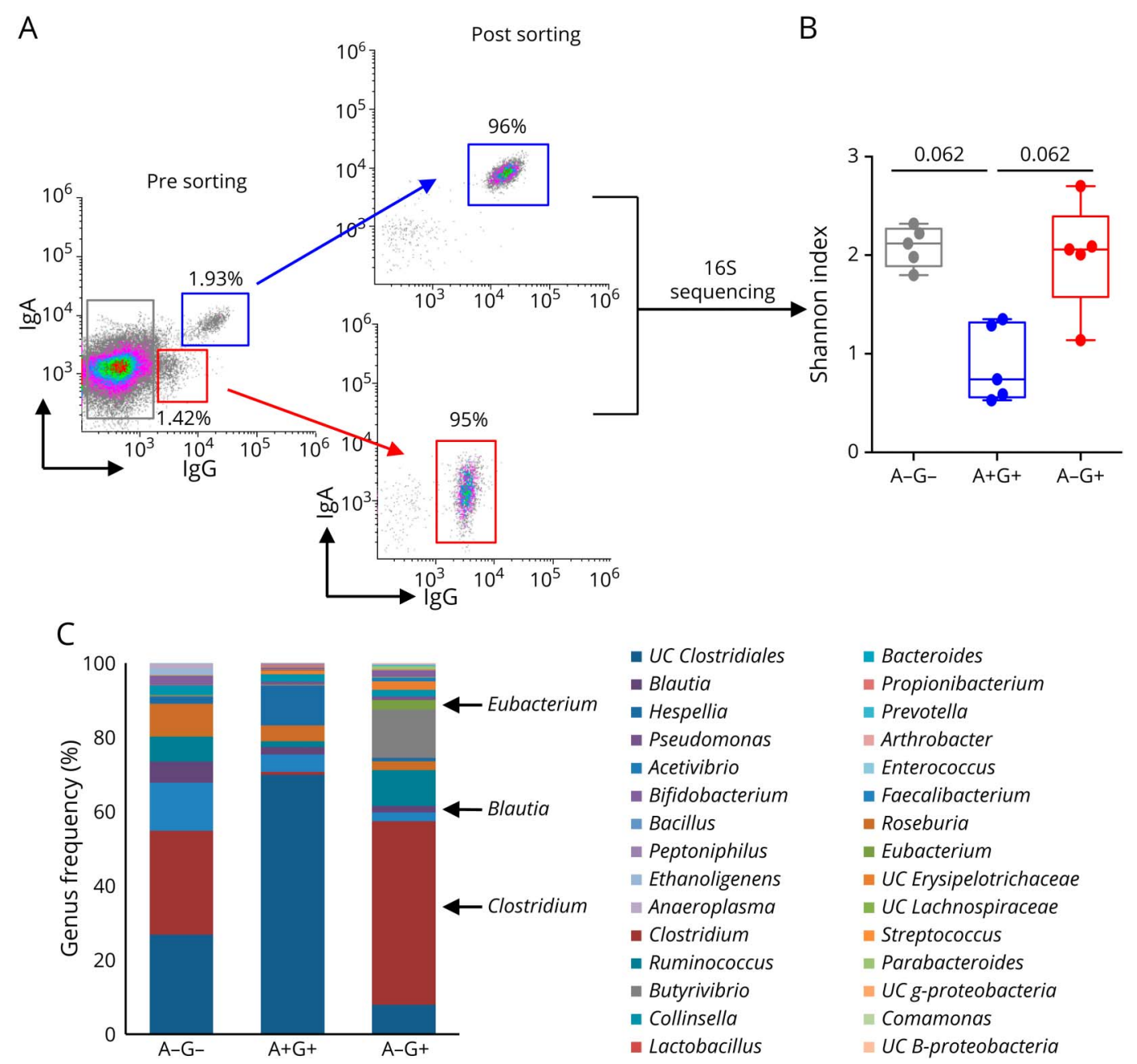

(A) Sorting strategy of $\operatorname{lgG}{ }^{+} \mid g A^{+}$and $\operatorname{lgG}{ }^{+} \mid g A^{-}$-coated bacteria in 5 patients with RR-MS. Composition of sorted fractions was next analyzed by using 165 rRNA sequencing. (B) Genera diversity in $\lg \mathrm{G}^{+} \lg \mathrm{A}^{+}$and $\lg \mathrm{G}^{+} \mathrm{Ig} \mathrm{A}^{-}$-sorted fractions calculated by using the Shannon index. (C) Median relative abundance of the 30 most frequent genera in sorted fractions from 1 representative RR-MS patient. MS = multiple sclerosis; RR = relapsing-remitting.

[0.1-16.4] and 2.5\% [1.3-5.4] in patients with RR-MS ( $\mathrm{n}=$ 32 ) and CIS ( $\mathrm{n}=12)$, respectively; $p<0.001$; figure $2, \mathrm{~B})$.

We then asked whether this observed loss of convergence was related to IgG responses only found in MS or to an increased MS microbiota reactivity to IgG in general. To address this issue, we compared MS and pooled healthy IgG reactivity to MS microbiota. As shown in figure 2, D, although pooled healthy IgG bound a smaller fraction of RR-MS microbiota, compared with autologous RR-MS IgG (1.9 [0-10]\% vs 6.7 $[0.5-17.1] \% ; \mathrm{n}=32 ; p<0.0001$; figure $2, \mathrm{D})$, pooled healthy IgG targets not only in vivo IgA-bound but also IgA-free RRMS microbiota $(0.7[0-6.4] \%$ vs $0.6[0-6.2] \% ; p=0.79$; figure 2, D), suggesting that MS microbiota are more prone to interact with IgG, regardless of their origin.

From this part, we conclude that the $\operatorname{IgA} / \operatorname{IgG}$ convergence rule does not apply to MS. A previously IgA-ignored fraction of MS microbiota is able to interact with IgG.

\section{Antimicrobiota IgG Spreading in MS}

It could be deduced from above that IgG binding to MS microbiota might extend beyond the usual bacterial repertoire of IgA targets that we and others previously defined. ${ }^{23,27}$ To decipher antimicrobiota IgG specificities in patients with MS with higher resolution, we next isolated IgG-bound bacteria by flow cytometry sorting and identified their taxonomy using $16 \mathrm{~S}$ rRNA sequencing (figure 3, A). To avoid confounding factors from IMD therapies, we sorted IgG-bound bacteria from untreated patients. We first examined microbial diversity by calculating the Shannon index and found a similar diversity in IgG-only and Ig-negative bacteria (2.06 [1.14-2.7] vs 2.12 $[1.8-2.32] ; n=5$; figure $3, B)$. In contrast, dually coated bacteria tended to exhibit a decreased microbial diversity in comparison with the previous fractions $(0.74[0.53-1.35] ; \mathrm{n}=5 ; p=0.062$; figure $3, \mathrm{~B})$, suggesting a state of restricted antimicrobiota secretory IgA diversity in MS. We observed that individual $\mathrm{IgA}^{+} \mathrm{IgG}^{+}$and $\mathrm{IgA}^{-} \mathrm{IgG}^{+}$bacterial repertoires were remarkably distinct in all tested patients (figure 3, C for back-to-back 

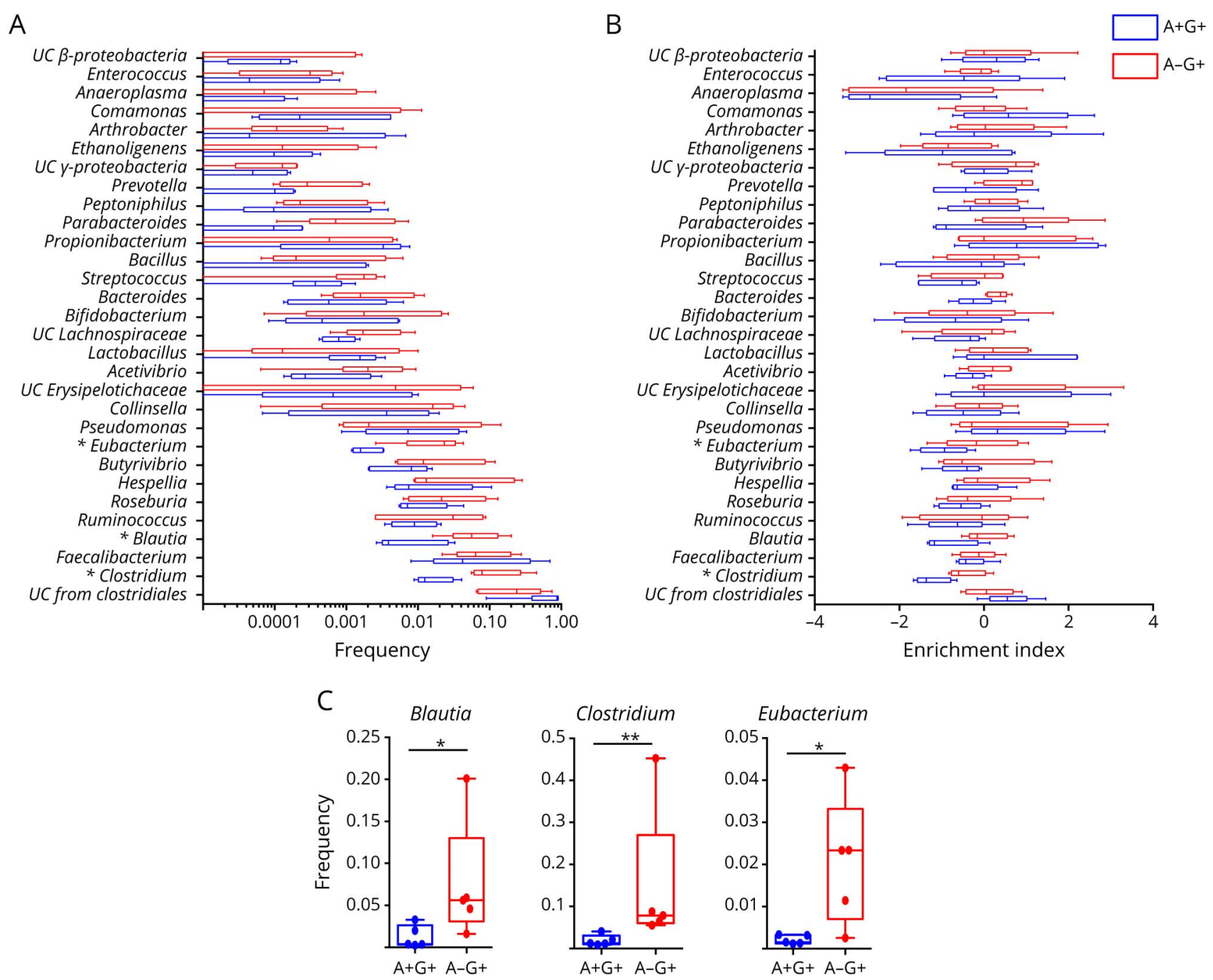

(A) Relative abundance of the 30 most frequent genera in $\lg \mathrm{G}^{+} \operatorname{IgA} \mathrm{A}^{+}$and $\operatorname{lgG} \mathrm{G}^{+} \lg \mathrm{A}^{-}$-sorted fractions, in blue and red, respectively. (B) El of the 30 most frequent genera in $\operatorname{lgG}{ }^{+} \lg A^{+}$and $\operatorname{lgG}{ }^{+} \mid g A^{-}$-sorted fractions compared, in blue and red, respectively. (C) Blautia, Clostridium, and Eubacterium frequencies in IgG ${ }^{+} \mid g A^{+}$and IgG $\lg A^{-}$fractions. For all box plots, each dot represents 1 donor, errors bars represent maximum and minimum values, and medians are indicated. $p$ Values were calculated by using the nonparametric Mann-Whitney test $(* p<0.05 ; * *<0.01)$. El = enrichment index; MS = multiple sclerosis.

taxonomic analysis of fecal $\operatorname{IgA}^{+} \operatorname{IgG}^{+}, \operatorname{IgA}^{-} \operatorname{IgG}^{+}$, and $\operatorname{IgA}^{-} \operatorname{IgG}^{-}$ fractions in a representative patient), supporting an IgG response spread beyond IgA-surveyed taxa. To quantitatively compare $\operatorname{IgA}^{-} \mathrm{IgG}^{+}$and $\operatorname{IgA}^{+} \operatorname{IgG}^{+}$microbial compositions in the studied population, we thereafter narrowed the analysis down to the 30 most frequent genera that were present in at least $80 \%$ of the Ig-sorted fractions. Three genera derived from Firmicutes: Blautia, Clostridium, and Eubacterium appeared preferentially targeted by MS serum IgG alone, as deduced from their compared frequencies in $\mathrm{IgA}^{-} \mathrm{IgG}^{+}$bacteria and $\mathrm{IgA}^{+} \mathrm{IgG}^{+}$sorted fractions $(0.06[0.02-0.2]$ vs $0.004[0.002-0.033] ; 0.07$ $[0.055-0.45]$ vs $0.003[0.009-0.041]$ and $0.023[0.003-0.04]$ vs 0.002 [0.001-0.003]; respectively, $p<0.05$; figure 4 , A-C). We sought to validate these observations by calculating a log-based EI that is not influenced by genera representation in the studied samples. We confirmed that both Clostridium and Eubacterium were predominant in $\operatorname{IgA}^{-} \operatorname{IgG}^{+}$- compared with $\operatorname{IgA}^{+} \operatorname{IgG}{ }^{+}$- sorted fractions (EI $-0.6[-0.83$ to 0.22$]$ vs $-1.37[-1.66$ to $0.64]$ and -0.18 [ -0.39 to 1.05$]$ vs -0.93 [ -1.74 to 0.19$]$; for Clostridium and Eubacterium, respectively; $p<0.05$; figure 4, B).

Taken together, these results demonstrate that MS is associated with a broad antimicrobiota systemic IgG response, with a variety of bacterial genera being preferentially targeted by MS IgG, compared with MS IgA. Because systemic IgG could reflect silent gut microbiota translocation episodes, ${ }^{23,28,29}$ these observations could support an enhanced bacterial translocation from the gut lumen to systemic compartments in patients with MS.

\section{Increased MS IgG Antibacterial Responses Confirmed at the Strain Level}

Bacterial identification remains at the genus level using $16 \mathrm{~S}$ rRNA sequencing. Using bacterial flow cytometry, we sought 

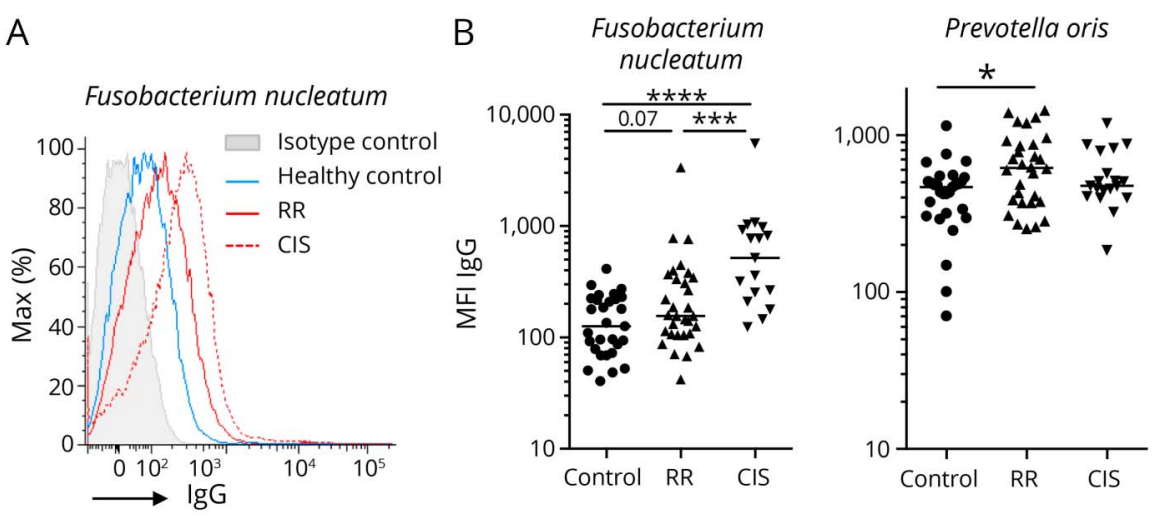

C Akkermansia muciniphila

Ruminococcus obeum
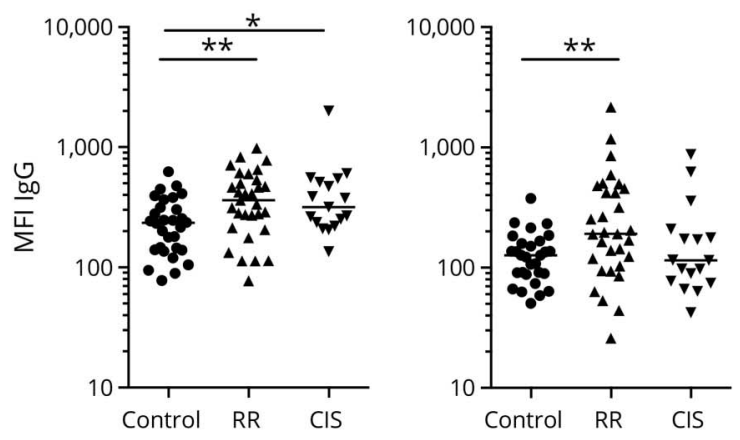

(A) Representative flow cytometry analysis of serum IgG binding to F nucleatum. Gray histogram represents isotype control; blue, red, and red dotted lines represent a healthy control, patient with RR-MS, and patient with CIS, respectively. (B) Flow cytometry analysis of serum IgG binding to IgA-unbound bacteria (from left to right: $F$ nucleatum and $P$ oris) in healthy donors $(\mathrm{n}=30)$, patients with RR-MS $(=32)$, and patients with CIS $(n=12)$. (C) Flow cytometry analysis of serum IgG binding to IgA-bound bacteria (from left to right: $A$ muciniphila and $R$ obeum $)$ in healthy donors $(n=30)$, patients with RR-MS (=32), and patients with CIS $(n=12)$. Dark bars represent medians. $p$ Values were calculated by using the nonparametric Mann-Whitney test ( $\left.{ }^{*} p<0.05 ;{ }^{* *} p<0.01 ; * \star * p<0.001\right)$; $\star \star \star \star x p<0.0001)$. MS = multiple sclerosis; RR = relapsing-remitting.

to determine whether increased antimicrobiota IgG reactivities could also be measured at the species level in patients with MS. We therefore selected representative bacterial strains that were previously described as secretory IgA targets in humans ( $A$ muciniphila, $B$ longum, and $R$ obeum) and 3 others that are not preferentially bound by IgA in humans $(B$ caccae, $F$ nucleatum, and $P$ oris $).{ }^{30-33}$ A majority of strains tested ( 4 of 6 ) tended to be more brightly stained by MS (RR and/or CIS) IgG that by control serum IgG (figure 5, A-C). Preferred MS IgG targets are not systematically preferred control IgA targets, as neither B longum nor B caccae were preferentially bound by MS IgG compared with control IgG (figure e-5, links.lww.com/NXI/A472). Of interest, we observed that $F$ nucleatum is particularly well opsonized by CIS serum, compared with healthy control serum, but also compared with RR serum (IgG median fluorescence intensity 518 [146-5.505] vs 126 [40.7-414] and 156 [42.1-3.350] in CIS, healthy control, and RR serums, respectively, figure 5, A-B). We conclude from this part that MS serum contains high titers of antimicrobiota IgG that can be measured against specific bacterial strains.

\section{Discussion}

We report an imbalance between systemic and secretory antimicrobiota antibody responses in patients with MS.
Antimicrobiota secretory IgA responses are impaired, whereas, at the same time, systemic IgG responses directed against autologous microbiota are increased, compared with healthy controls. Importantly, although we found MS-associated gut microbiota alterations, the systemic IgG responses observed were not directed to taxa overrepresented in MS microbiota. Furthermore, low proportions of IgA-coated bacteria among fecal microbiota are associated with disease severity. Consistently with the latter observation, Rojas et al. ${ }^{34}$ have recently reported that proportions of IgA-coated bacteria among fecal microbiota are decreased in patients with relapsing MS compared with inactive patients. Reduced proportions of fecal $\operatorname{IgA}^{+}$bacteria might result from reduced secretory IgA levels in relation with IgA-secreting cells egress out of the gut mucosa. Previous works indeed shed light on the dynamic trafficking of intraepithelial CD4 T cells between gut and an inflamed CNS, ${ }^{35}$ and also of IgA-producing cells between gut and bone marrow. ${ }^{36}$ In the EAE model, commensal-reactive IgA-producing cells regulate inflammation via the production IL10 after their migration in the CNS. Pröbstel et al. recently demonstrated that gut microbiota IgA-producing cells infiltrate the CNS in patients with MS leading to an increase in in situ IgA production during MS relapses. However, commensal-specific IgA does not cross-react with brain tissue. ${ }^{37}$ Further studies are required to assess the role of gut-derived IgA-producing cells in MS pathophysiology. Defective IgA binding to gut microbiota in disabled patients with MS might be also related to microbial community alterations. 
Impaired IgA-mediated microbiota survey might also favor bacterial translocation and induction of systemic IgG responses, as we previously described in patients with IgA deficiency. ${ }^{23}$ Numerous studies underline that IgG typically present in the CSF of the patients might play a role in MS pathogenesis. ${ }^{38-40}$ IgG purified from patients with MS increases mouse CNS demyelination and exacerbates EAE. ${ }^{41}$ The main clinical evidence for a potential pathogenic role for antibodies in MS is the benefit of antibody removal in a subset of patients with acute neurologic symptoms. ${ }^{42,43}$ However, what triggers oligoclonal antibody responses observed in MS CSF remains a mystery. ${ }^{38-40}$ Antimicrobiota antibodies are frequently crossreactive with self-antigens. ${ }^{44-46}$ Cross-reactivity is probably an essential antimicrobial antibody feature, enabling control of a large diversity of gut commensals and invading pathogens ${ }^{47,48}$ but is also associated with a theoretical risk of autoimmunity. It has indeed been very recently proposed that some pathogenic immune responses associated with lupus ${ }^{49,50}$ or myocarditis ${ }^{51}$ can be triggered by commensal bacteria through a molecular mimicry mechanism. Of interest, more than 20 bacterial species, well represented in human gut microbiota, express proteins that contain potentially encephalitogenic peptides, i.e.,: highly homologous to myelin basic protein (MBP) or myelin oligodendrocyte protein. In particular, 4 proteins expressed by $F$ nucleatum have been identified as potentially encephalitogenic. ${ }^{52}$ Moreover, 3 proteins expressed by members of the Clostridium genera were described to be homologous to MBP. ${ }^{52}$ We report that RR-MS, and even more so CIS IgG, very brightly stain $F$ nucleatum. We also report that the Clostridium genus is significantly more targeted by systemic MS IgG than by IgA. These observations open new avenues for exploring the hypothesis that immune responses induced by commensal antigens might play a role in MS pathogenesis.

Enhanced induction of antimicrobiota $\operatorname{IgG}$ could also be a consequence of intestinal barrier dysfunction in MS. Indeed, not only blood-brain barrier defects have been reported in MS but also a state of increased intestinal permeability characterized by higher lactulose/mannitol urinary ratios, increased lipopolysaccharide plasma levels and associated with increased plasma zonulin, a regulator of epithelial and endothelial barrier functions. ${ }^{53-55}$ In the EAE model, such alterations preceded the onset of neurologic symptoms. ${ }^{56} \mathrm{It}$ is therefore conceivable that bacterial translocation could occur at early stages of the disease and account for the increased antimicrobiota IgG responses we observe as early as the CIS stage. Systemic antimicrobiota IgG responses are likely to mirror microbiota composition at the individual level. We therefore tested some of the bacterial species differentially identified between MS and healthy donor gut microbiota. $2,4,5$ We observed that patients with RR-MS and CISharbor elevated serum anti-A muciniphila IgG reactivities compared with controls. These results are in line with the higher levels of anti-A muciniphila antibodies detected in CSF of patients with MS. ${ }^{57}$ Of interest, a greater $A$ muciniphila prevalence in MS gut microbiota has been shown in previous reports. ${ }^{2,5} \mathrm{~A}$ positive correlation between $A$ muciniphila abundance and gene expression in $\mathrm{T}$ cells and monocytes involved in key pathways previously implicated in MS pathogenesis was also reported..$^{5}$ Located in close vicinity with the intestinal cells, $A$ muciniphila has also been reported to promote Th1 lymphocyte differentiation, a T-cell subset classically associated with MS pathogenesis. ${ }^{2,58}$ Altogether, although only correlative, these observations suggest a role for $A$ muciniphila in driving exacerbated host immune response in MS.

As mentioned above, signs of increased intestinal permeability preceded the onset of neurologic symptoms in the EAE model. ${ }^{56}$ It would now remain to determine to which extent antimicrobiota IgG monitoring could represent a tool to predict MS progression. Not all patients with CIS progress to full blown MS. Baseline lesions, age at onset, and short time delay between the first 2 relapses provide some predictive value for disease progression, yet remain flawed. ${ }^{59,60}$ Whether microbial/host signatures including immune responses to commensals could help to distinguish between stable cases and future progressive cases should be now tested in larger studies.

In summary, we have found quantitative and qualitative alterations of the antimicrobiota antibody response in patients with MS involving peculiar bacterial taxa. We propose that such peculiar IgG responses associated with MS could represent a lead in the quest for antigenic drivers, possibly implicated in MS pathogenesis through a molecular mimicry mechanism. We also propose that antimicrobiota fingerprints should be more widely used in further studies to seek for correlates with disease status. Finally, microbiota manipulation is now a recognized therapeutic option in the clinic. ${ }^{61}$ How our results could translate into treatments should therefore be tested in murine MS models.

\section{Acknowledgment}

The authors thank the patients who agreed to participate in this study and doctors and nurses from the Neurology Department (Hôpital Pitié-Salpêtrière, 75013 Paris, France, and Hôpital Fondation Adolphe de Rotschild, 75019 Paris, France) who participated in this study.

\section{Study Funding}

The study was supported by a grant from Fondation pour l'Aide à la Recherche sur la Sclérose en Plaques (ARSEP) and by a proof of concept grant (CoPoc) from Inserm Transfert, Paris, France.

\section{Disclosure}

G. Gorochov is a scientific advisor for Luxia Scientific, France. The other authors report no disclosures relevant to the manuscript. Go to Neurology.org/NN for full disclosures.

\section{Publication History}

Received by Neurology: Neuroimmunology \& Neuroinflammation July 7, 2020. Accepted in final form March 9, 2021. 
Appendix Authors

\begin{tabular}{ll}
\hline Name & Location \\
\hline Delphine & Sorbonne Université, \\
Sterlin, & Inserm, Centre \\
PharmD, & d'Immunologie et des \\
PhD & Maladies Infectieuses \\
& (CIMI-Paris), AP-HP Hôpital \\
& Pitié-Salpêtrière, Paris, \\
& France
\end{tabular}

\begin{tabular}{ll}
\hline Martin & Sorbonne Université, \\
Larsen, PhD & Inserm, Centre \\
& d'Immunologie et des \\
& Maladies Infectieuses \\
& (CIMI-Paris), AP-HP Hôpital \\
& Pitié-Salpêtrière, Paris, \\
& France
\end{tabular}

Contribution

Major role in the acquisition, analysis, and interpretation of data and drafted the manuscript

Designed and
conceptualized the study

\begin{tabular}{ll}
\hline Jehane & Sorbonne Université, \\
Fadlallah, & Inserm, Centre \\
MD, PhD & d'Immunologie et des \\
& Maladies Infectieuses \\
& (CIMI-Paris), AP-HP Hôpital \\
& Pitié-Salpêtrière, Paris, \\
& France
\end{tabular}

\begin{tabular}{|c|c|c|}
\hline $\begin{array}{l}\text { Christophe } \\
\text { Parizot, MS }\end{array}$ & $\begin{array}{l}\text { Sorbonne Université, } \\
\text { Inserm, Centre } \\
\text { d'Immunologie et des } \\
\text { Maladies Infectieuses } \\
\text { (CIMI-Paris), AP-HP Hôpital } \\
\text { Pitié-Salpêtrière, Paris, } \\
\text { France }\end{array}$ & $\begin{array}{l}\text { Major role in the } \\
\text { acquisition, analysis, and } \\
\text { interpretation of data }\end{array}$ \\
\hline $\begin{array}{l}\text { Marina } \\
\text { Vignes, } \\
\text { PharmD }\end{array}$ & $\begin{array}{l}\text { Sorbonne Université, } \\
\text { Inserm, Centre } \\
\text { d'Immunologie et des } \\
\text { Maladies Infectieuses } \\
\text { (CIMI-Paris), AP-HP Hôpital } \\
\text { Pitié-Salpêtrière, Paris, } \\
\text { France }\end{array}$ & $\begin{array}{l}\text { Major role in the acquisition } \\
\text { of data }\end{array}$ \\
\hline $\begin{array}{l}\text { Gaëlle } \\
\text { Autaa, MS }\end{array}$ & $\begin{array}{l}\text { Sorbonne Université, } \\
\text { Inserm, Centre } \\
\text { d'Immunologie et des } \\
\text { Maladies Infectieuses } \\
\text { (CIMI-Paris), AP-HP Hôpital } \\
\text { Pitié-Salpêtrière, Paris, } \\
\text { France }\end{array}$ & $\begin{array}{l}\text { Major role in the acquisition } \\
\text { of data }\end{array}$ \\
\hline
\end{tabular}

\begin{tabular}{|c|c|c|}
\hline $\begin{array}{l}\text { Karim } \\
\text { Dorgham, } \\
\text { PhD }\end{array}$ & $\begin{array}{l}\text { Sorbonne Université, } \\
\text { Inserm, Centre } \\
\text { d'Immunologie et des } \\
\text { Maladies Infectieuses } \\
\text { (CIMI-Paris), AP-HP Hôpital } \\
\text { Pitié-Salpêtrière, Paris, } \\
\text { France }\end{array}$ & $\begin{array}{l}\text { Major role in the acquisition } \\
\text { of data }\end{array}$ \\
\hline $\begin{array}{l}\text { Catherine } \\
\text { Juste, PhD }\end{array}$ & $\begin{array}{l}\text { Université Paris-Saclay, } \\
\text { INRAE, AgroParisTech, } \\
\text { Micalis Institute, Jouy-en- } \\
\text { Josas, France }\end{array}$ & $\begin{array}{l}\text { Major role in the acquisition } \\
\text { of data }\end{array}$ \\
\hline $\begin{array}{l}\text { Patricia } \\
\text { Lepage, PhD }\end{array}$ & $\begin{array}{l}\text { Université Paris-Saclay, } \\
\text { INRAE, AgroParisTech, } \\
\text { Micalis Institute, Jouy-en- } \\
\text { Josas, France }\end{array}$ & $\begin{array}{l}\text { Major role in the acquisition } \\
\text { of data }\end{array}$ \\
\hline $\begin{array}{l}\text { Jennifer } \\
\text { Aboab, MD }\end{array}$ & $\begin{array}{l}\text { Hôpital Ophtalmologique } \\
\text { Adolphe de Rothschild, } \\
\text { Département de } \\
\text { Neurologie, Paris, France }\end{array}$ & $\begin{array}{l}\text { Major role in the acquisition } \\
\text { of data }\end{array}$ \\
\hline $\begin{array}{l}\text { Savine } \\
\text { Vicart, MD }\end{array}$ & $\begin{array}{l}\text { Sorbonne Université, } \\
\text { Département de } \\
\text { Neurologie, AP-HP Hôpital } \\
\text { Pitié-Salpêtrière, Paris, } \\
\text { France }\end{array}$ & $\begin{array}{l}\text { Major role in the acquisition } \\
\text { of data and revised the } \\
\text { manuscript for intellectual } \\
\text { content }\end{array}$ \\
\hline
\end{tabular}

Appendix (continued)

\begin{tabular}{|c|c|c|}
\hline Name & Location & Contribution \\
\hline $\begin{array}{l}\text { Elisabeth } \\
\text { Maillart, MD }\end{array}$ & $\begin{array}{l}\text { Sorbonne Université, } \\
\text { Département de } \\
\text { Neurologie, AP-HP Hôpital } \\
\text { Pitié-Salpêtrière, Paris, } \\
\text { France }\end{array}$ & $\begin{array}{l}\text { Major role in the acquisition } \\
\text { of data and revised the } \\
\text { manuscript for intellectual } \\
\text { content }\end{array}$ \\
\hline $\begin{array}{l}\text { Olivier Gout, } \\
\text { MD }\end{array}$ & $\begin{array}{l}\text { Hôpital Ophtalmologique } \\
\text { Adolphe de Rothschild, } \\
\text { Département de } \\
\text { Neurologie, Paris, France }\end{array}$ & $\begin{array}{l}\text { Designed and } \\
\text { conceptualized the study } \\
\text { and revised the manuscript } \\
\text { for intellectual content }\end{array}$ \\
\hline $\begin{array}{l}\text { Catherine } \\
\text { Lubetzki, } \\
\text { MD, PhD }\end{array}$ & $\begin{array}{l}\text { Sorbonne Université, } \\
\text { Département de } \\
\text { Neurologie, AP-HP Hôpital } \\
\text { Pitié-Salpêtrière, Paris, } \\
\text { France }\end{array}$ & $\begin{array}{l}\text { Designed and } \\
\text { conceptualized the study } \\
\text { and revised the manuscript } \\
\text { for intellectual content }\end{array}$ \\
\hline $\begin{array}{l}\text { Romain } \\
\text { Deschamps, } \\
\text { MD }\end{array}$ & $\begin{array}{l}\text { Hôpital Ophtalmologique } \\
\text { Adolphe de Rothschild, } \\
\text { Département de } \\
\text { Neurologie, Paris, France }\end{array}$ & $\begin{array}{l}\text { Designed and } \\
\text { conceptualized the study } \\
\text { and revised the manuscript } \\
\text { for intellectual content }\end{array}$ \\
\hline $\begin{array}{l}\text { Caroline } \\
\text { Papeix, MD }\end{array}$ & $\begin{array}{l}\text { Sorbonne Université, } \\
\text { Département de } \\
\text { Neurologie, AP-HP Hôpital } \\
\text { Pitié-Salpêtrière, Paris, } \\
\text { France }\end{array}$ & $\begin{array}{l}\text { Designed and } \\
\text { conceptualized the study } \\
\text { and revised the manuscript } \\
\text { for intellectual content }\end{array}$ \\
\hline $\begin{array}{l}\text { Guy } \\
\text { Gorochov, } \\
\text { MD, PhD }\end{array}$ & $\begin{array}{l}\text { Sorbonne Université, } \\
\text { Inserm, Centre } \\
\text { d'Immunologie et des } \\
\text { Maladies Infectieuses } \\
\text { (CIMI-Paris), AP-HP Hôpital } \\
\text { Pitié-Salpêtrière, Paris, } \\
\text { France }\end{array}$ & $\begin{array}{l}\text { Designed and } \\
\text { conceptualized the study } \\
\text { and drafted and revised the } \\
\text { manuscript for intellectual } \\
\text { content }\end{array}$ \\
\hline
\end{tabular}

\section{References}

1. Berer K, Mues M, Koutrolos M, et al. Commensal microbiota and myelin autoantigen cooperate to trigger autoimmune demyelination. Nature 2011;479:538-541.

2. Cekanaviciute E, Yoo BB, Runia TF, et al. Gut bacteria from multiple sclerosis patients modulate human T cells and exacerbate symptoms in mouse models. Proc Natl Acad Sci USA 2011;114:10713-10718.

3. Miyake S, Kim S, Suda W, et al. Dysbiosis in the gut microbiota of patients with multiple sclerosis, with a striking depletion of species belonging to clostridia XIVa and IV clusters. PLoS One 2015;10:e137429.

4. Chen J, Chia N, Kalari KR, et al. Multiple sclerosis patients have a distinct gut microbiota compared to healthy controls. Sci Rep 2016;6:28484.

5. Jangi S, Gandhi R, Cox LM, et al. Alterations of the human gut microbiome in multiple sclerosis. Nat Commun 2016;7:12015.

6. Berer K, Gerdes LA, Cekanaviciute E, et al. Gut microbiota from multiple sclerosis patients enables spontaneous autoimmune encephalomyelitis in mice. Proc Natl Acad Sci USA 2017;114:10719-10724.

7. Tremlett H, Fadrosh DW, Faruqi AA, et al. Gut microbiota in early pediatric multiple sclerosis: a case-control study. Eur J Neurol 2016;23:1308-1321.

8. Reynders T, Devolder L, Valles-Colomer M, et al. Gut microbiome variation is associated to Multiple Sclerosis phenotypic subtypes. Ann Clin Transl Neurol 2020;7: 406-419.

9. Katz Sand I, Zhu Y, Ntranos A, et al. Disease-modifying therapies alter gut microbial composition in MS. Neurol Neuroimmunol Neuroinflamm 2019;6:e517.

10. Varrin-Doyer M, Spencer CM, Schulze-Topphoff U, et al. Aquaporin 4-specific T cells in neuromyelitis optica exhibit a Th17 bias and recognize Clostridium ABC transporter. Ann Neurol 2012;72:53-64.

11. Cree BA, Spencer CM, Varrin-Doyer M, Baranzini SE, Zamvil SS. Gut microbiome analysis in neuromyelitis optica reveals overabundance of Clostridium perfringens. Ann Neurol 2016;80:443-447.

12. Jacobs BC, van Doorn PA, Schmitz PI, et al. Campylobacter jejuni infections and antiGM1 antibodies in Guillain-Barré syndrome. Ann Neurol 1996;40:181-187.

13. Shu XM, Cai FC, Zhang XP. Carbohydrate mimicry of Campylobacter jejuni lipooligosaccharide is critical for the induction of anti-GM1 antibody and neuropathy. Muscle Nerve 2006;33:225-231.

14. Polman $\mathrm{CH}$, Reingold SC, Banwell B, et al. Diagnostic criteria for multiple sclerosis: 2010 Revisions to the McDonald criteria. Ann Neurol 2011;69:292-302.

15. Kurtzke JF. Rating neurologic impairment in multiple sclerosis: an expanded disability status scale (EDSS). Neurology 1983;33:1444-1452. 
16. Dalton CM, Brex PA, Miszkiel KA, et al. Application of the new McDonald criteria to patients with clinically isolated syndromes suggestive of multiple sclerosis. Ann Neurol 2002;52:47-53.

17. Miller DH, Chard DT, Ciccarelli O. Clinically isolated syndromes. Lancet Neurol 2012;11:157-169.

18. Juste C, Kreil DP, Beauvallet C, et al. Bacterial protein signals are associated with Crohn's disease. Gut 2014;63:1566-1577.

19. Fadlallah J, El Kafsi H, Sterlin D, et al. Microbial ecology perturbation in human IgA deficiency. Sci Transl Med 2018; 10:eaan1217.

20. Godon JJ, Zumstein E, Dabert P, Habouzit F, Moletta R. Molecular microbial diversity of an anaerobic digestor as determined by small-subunit rDNA sequence analysis. Appl Environ Microbiol 1997;63:2802-2813.

21. Moor K, Fadlallah J, Toska A, et al. Analysis of bacterial-surface-specific antibodies in body fluids using bacterial flow cytometry. Nat Protoc 2016;11:1531-1553.

22. Caporaso JG, Kuczynski J, Stombaugh J, et al. QIIME allows analysis of highthroughput community sequencing data. Nat Methods 2010;7:335-336.

23. Fadlallah J, Sterlin D, Fieschi C, et al. Synergistic convergence of microbiota-specific systemic IgG and secretory IgA. J Allergy Clin Immunol 2019;143:1575-1585.e4.

24. Kurtzke JF. Rating neurologic impairment in multiple sclerosis: an expanded disability status scale (EDSS). Neurology 1983;33:1444-1452.

25. Haas A, Zimmermann $\mathrm{K}$, Graw F, et al. Systemic antibody responses to gut commensal bacteria during chronic HIV-1 infection. Gut 2011;60:1506-1519.

26. Harmsen HJM, Pouwels SD, Funke A, Bos NA, Dijkstra G. Crohn's disease patients have more IgG-binding fecal bacteria than controls. Clin Vaccin Immunol 2012;19:515-521.

27. Koch MA, Reiner GL, Lugo KA, et al. Maternal IgG and IgA antibodies dampen mucosal $\mathrm{T}$ helper cell responses in early life. Cell 2016;165:827-841.

28. Christmann BS, Abrahamsson TR, Bernstein CN, et al. Human seroreactivity to gut microbiota antigens. J Allergy Clin Immunol 2015;136:1378-1385.e1-5.

29. Mannon PJ. Systemic antibody responses to gut commensal bacteria: how and why do I know you? J Allergy Clin Immunol 2019;143:1353-1354.

30. D'Auria G, Peris-Bondia F, Džunková M, et al. Active and secreted IgA-coated bacterial fractions from the human gut reveal an under-represented microbiota core. Sci Rep 2013;3:3515.

31. Palm NW, de Zoete MR, Cullen TW, et al. Immunoglobulin A coating identifies colitogenic bacteria in inflammatory bowel disease. Cell 2014;158:1000-1010.

32. Kau AL, Planer JD, Liu J, et al. Functional characterization of IgA-targeted bacterial taxa from undernourished Malawian children that produce diet-dependent enteropathy. Sci Transl Med 2015;7:276ra24.

33. Magri G, Comerma L, Pybus M, et al. Human secretory IgM emerges from plasma cells clonally related to gut memory B cells and targets highly diverse commensals. Immunity 2017;47:118-134.e8.

34. Rojas OL, Pröbstel AK, Porfilio EA, et al. Recirculating intestinal IgA-producing cells regulate neuroinflammation via IL-10. Cell 2019;176:610-624.e18

35. Kadowaki A, Miyake S, Saga R, Chiba A, Mochizuki H, Yamamura T. Gut environment-induced intraepithelial autoreactive CD4(+) T cells suppress central nervous system autoimmunity via LAG-3. Nat Commun 2016;7:11639.

36. Wilmore JR, Gaudette BT, Gomez Atria D, et al. Commensal microbes induce serum IgA responses that protect against polymicrobial sepsis. Cell Host Microbe 2018;23:302-311.e3.

37. Pröbstel A-K, Zhou X, Baumann R, et al. Gut microbiota-specific IgA(+) B cells traffic to the CNS in active multiple sclerosis. Sci Immunol 2020;5:eabc7191.

38. Thompson AJ, Banwell BL, Barkhof F, et al. Diagnosis of multiple sclerosis: 2017 revisions of the McDonald criteria. Lancet Neurol 2018;17:162-173.

39. Tomescu-Baciu A, Johansen JN, Holmøy T, et al. Persistence of intrathecal oligoclonal B cells and IgG in multiple sclerosis. J Neuroimmunol 2019;333:576966.
40. Graner M, Pointon T, Manton S, et al. Oligoclonal IgG antibodies in multiple sclerosis target patient-specific peptides. PLoS One 2020;15:e228883.

41. Pedotti R, Musio S, Scabeni S, et al. Exacerbation of experimental autoimmune encephalomyelitis by passive transfer of IgG antibodies from a multiple sclerosis patient responsive to immunoadsorption. J Neuroimmunology 2013;262:19-26.

42. Keegan M, König F, McClelland R, et al. Relation between humoral pathological changes in multiple sclerosis and response to therapeutic plasma exchange. Lancet 2005;366:579-582.

43. Magaña SM, Keegan BM, Weinshenker BG, et al. Beneficial plasma exchange response in central nervous system inflammatory demyelination. Arch Neurol 2011;68 870-878.

44. Benckert J, Schmolka N, Kreschel C, et al. The majority of intestinal IgA+ and IgG+ plasmablasts in the human gut are antigen-specific. J Clin Invest 2011;121:1946-1955.

45. Rollenske T, Szijarto V, Lukasiewicz J, et al. Cross-specificity of protective human antibodies against Klebsiella pneumoniae LPS O-antigen. Nat Immunol 2018;19: 617-624.

46. Sterlin D, Fadlallah J, Adams O, et al. Human IgA binds a diverse array of commensal bacteria. J Exp Med 2020;217:217.

47. Pabst O, Slack E. IgA and the intestinal microbiota: the importance of being specific. Mucosal Immunol 2020;13:12-21.

48. Sterlin D, Fadlallah J, Slack E, Gorochov G. The antibody/microbiota interface in health and disease. Mucosal Immunol 2020;13:3-11

49. Greiling TM, Dehner C, Chen X, et al. Commensal orthologs of the human autoantigen Ro60 as triggers of autoimmunity in lupus. Sci Transl Med 2018; 10:eaan2306.

50. Manfredo Vieira S, Hiltensperger M, Kumar V, et al. Translocation of a gut pathobiont drives autoimmunity in mice and humans. Science 2018;359:1156-1161.

51. Gil-Cruz C, Perez-Shibayama C, De Martin A, et al. Microbiota-derived peptide mimics drive lethal inflammatory cardiomyopathy. Science 2019;366:881-886.

52. Westall FC. Molecular mimicry revisited: gut bacteria and multiple sclerosis. J Clin Microbiol 2006;44:2099-2104.

53. Fasano A. Zonulin and its regulation of intestinal barrier function: the biological door to inflammation, autoimmunity, and cancer. Physiol Rev 2011;91:151-175.

54. Teixeira B, Bittencourt VC, Ferreira TB, et al. Low sensitivity to glucocorticoid inhibition of in vitro Th17-related cytokine production in multiple sclerosis patients is related to elevated plasma lipopolysaccharide levels. Clin Immunol 2013;148:209-218

55. Buscarinu MC, Cerasoli B, Annibali V, et al. Altered intestinal permeability in patients with relapsing-remitting multiple sclerosis: a pilot study. Mult Scler 2017;23:442-446.

56. Nouri M, Bredberg A, Weström B, Lavasani S. Intestinal barrier dysfunction develops at the onset of experimental autoimmune encephalomyelitis, and can be induced by adoptive transfer of auto-reactive T cells. PLoS One 2014;9:e106335.

57. Vallino A, Dos Santos A, Mathé CV, et al. Gut bacteria Akkermansia elicit a specific IgG response in CSF of patients with MS. Neurol Neuroimmunol Neuroinflamm 2020;7.

58. Derrien M, Van Baarlen P, Hooiveld G, Norin E, Müller M, de Vos WM. Modulation of mucosal immune response, tolerance, and proliferation in mice colonized by the mucin-degrader Akkermansia muciniphila. Front Microbiol 2011;2:166.

59. Kuhle J, Disanto G, Dobson R, et al. Conversion from clinically isolated syndrome to multiple sclerosis: a large multicentre study. Mult Scler 2015;21:1013-1024.

60. Tintore M, Arrambide G, Otero-Romero S, et al. The long-term outcomes of CIS patients in the Barcelona inception cohort: looking back to recognize aggressive MS Mult Scler 2020;26:1658-1669.

61. van Nood E, Vrieze A, Nieuwdorp M, et al. Duodenal infusion of donor feces for recurrent Clostridium difficile. $N$ Engl J Med 2013;368:407-415. 


\section{Neurology \\ Neuroimmunology \& Neuroinflammation}

Perturbed Microbiota/Immune Homeostasis in Multiple Sclerosis

Delphine Sterlin, Martin Larsen, Jehane Fadlallah, et al.

Neurol Neuroimmunol Neuroinflamm 2021;8;

DOI 10.1212/NXI.0000000000000997

This information is current as of May 11, 2021

\section{Updated Information \& Services}

References

Subspecialty Collections

Permissions \& Licensing

Reprints including high resolution figures, can be found at:

http://nn.neurology.org/content/8/4/e997.full.html

This article cites 60 articles, 11 of which you can access for free at: http://nn.neurology.org/content/8/4/e997.full.html\#\#ref-list-1

This article, along with others on similar topics, appears in the following collection(s):

All Immunology

http://nn.neurology.org//cgi/collection/all_immunology

Autoimmune diseases

http://nn.neurology.org//cgi/collection/autoimmune_diseases

Multiple sclerosis

http://nn.neurology.org//cgi/collection/multiple_sclerosis

Information about reproducing this article in parts (figures,tables) or in its entirety can be found online at:

http://nn.neurology.org/misc/about.xhtml\#permissions

Information about ordering reprints can be found online:

http://nn.neurology.org/misc/addir.xhtml\#reprintsus

Neurol Neuroimmunol Neuroinflamm is an official journal of the American Academy of Neurology.

Published since April 2014, it is an open-access, online-only, continuous publication journal. Copyright

Copyright $\odot 2021$ The Author(s). Published by Wolters Kluwer Health, Inc. on behalf of the American

Academy of Neurology.. All rights reserved. Online ISSN: 2332-7812.

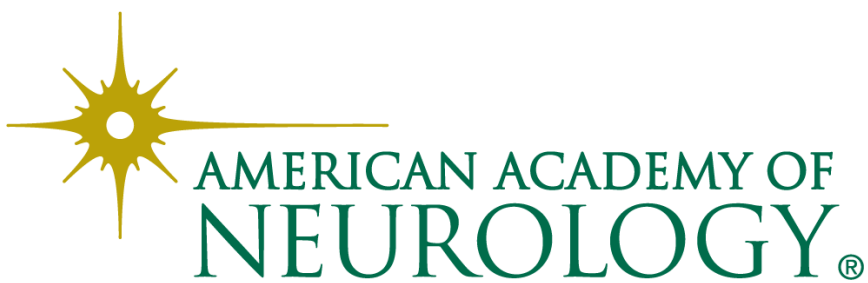

